\title{
DOES MIDDLE INCOME TRAP EXIST?: EVIDENCE FROM EMERGING ECONOMIES: E7
}

COUNTRIES FOR 1969-2015

Burcu YAVUZ TIFTIKÇIGIL*1,

Burak GÜRIŞ**, and

Yaşar Serhat YAȘGÜL ***

Abstract: The E7 countries (China, India, Brazil, Russia, Mexico, Indonesia and Turkey) that have been growing fast since 1990s have been under the middle income country category according to the income category classification of the World Bank for a long period of time. Researchers have been interested especially in emerging economies that have not been able to move up from the middle income category to the high income category and this has led to the initiation of what's called the 'middle income trap' (MIT) discussions in literature. The MT is generally defined as the countries under the middle income category failing to move up to the high income category. Therefore, the purpose of this study is to identify the presence of MIT in E7 countries that hold an important position in global economy. The unit root tests were used in the empirical phase of the study. This study's difference from other studies is the fact that both the time series and the panel data unit root tests were used both in linear and nonlinear forms, thus preventing the misleading results created by choosing the wrong model specification.

The USA was taken as the reference country in the study and the GNI per capita according to the Atlas method (current US\$) data of the World Bank was used for the E7 countries for the period 1969-2015. To achieve consistency in the analysis results, Russia was not included in the model as there were no data available for the same period for Russia given the fact that the same timeframe should be taken as the basis for all countries. The empirical analysis showed that the E7 countries do not fall into the MIT.

Key Words: Middle-income trap, middle-income countries, Emerging 7 Countries (E7), Unit Root Tests

Jel Codes: 0500, 0470, C22, C23

\section{$1 \quad$ Introduction}

According to various projections, the economies of the E7 countries (China, India, Brazil, Russia, Mexico, Indonesia and Turkey) that have been displaying a high growth trend since 1990s will be bigger than the current G7 countries (the USA, Japan, Germany, France, the UK, Italy and Canada) by 2020. However, the E7 countries that have been displaying a high growth trend and potential have been under the middle income category for several years. None of these countries have achieved to be classified under the high income category. This situation seen especially in emerging economies has led researchers to test the presence of what is called the 'middle income trap' (MIT) in these countries.

The term "middle income trap" (MIT) has been widely used in the literature, without a certain definition and a formal test. However, the MIT can generally be defined as the failure of the middle income countries in terms of per capita income to move up to the high income countries category.

Given their important position in global economy, it is important to identify whether the E7 countries fall into the MIT or not. Therefore, the purpose of this study is to test the presence of MT from the perspective of E7 countries.

\footnotetext{
*Corresponding Author, Department of International Trade and Finance, Istanbul Gedik University, Istanbul, Turkey (Email: burcu.tiftikcigil@gedik.edu.tr) (Adress: Istanbul Gedik University Kartal Campus, Cumhuriyet Mah. İlkbahar Sk. A Blok, Kat 7, PC: 34876Yakacık-Kartal/ Istanbul/ Turkey) **Department of Econometrics, Istanbul University, Istanbul, Turkey (Email: bguris@istanbul.edu.tr) ***Department of Economics, Marmara University, Istanbul, Turkey (yserhat@marmara.edu.tr)
} 
The methodology introduced by Robertson and Ye (2013) is going to be used to test empirically the presence of MIT. By using unit root tests according to this methodology, it is decided whether the countries are in the MIT. The empirical problem encountered in unit root tests is about choosing the right test procedure. Not choosing the right test procedure leads to misleading test results. The unit root tests could be classified as linear and nonlinear in both time series and panel data. Unit root tests could be classified as linear and nonlinear both for time series and panel data. This study is different from other studies in the sense that both time series and panel data unit root tests are used in both linear and nonlinear forms. This helped to eliminate the situation as shown in the study by Enders and Granger (1998) that standard tests for unit root and co-integration all have lower power in the presence of misspecified model dynamics.

The GNI per capita according to the Atlas method (current US\$) of the World Bank was used for the period 1969-2015. This method was preferred as the World Bank uses the Atlas method for the calculation of the countries' income categories. The USA has been the global leader of economy since 1920s. Therefore, the USA is considered as a reference wealthy economy that has been growing in a balanced fashion in this study. To achieve consistency in the study results, the same period should be analyzed for all countries and as no data were available for Russia for this period, Russia was not included in the study.

\section{Classification of Economies according to Income Categories and E7 Countries}

There are two main approaches used to classify countries according to income categories. One of these is the Catch-Up Index (CUI) and the other one is the measurement of the World Bank.

The Catch-Up Index measures the performance of 35 countries - the EU member states and the candidate and potential candidate countries across four categories: Economy, Quality of Life, Democracy and Governance. There are scores given for each category and an Overall Score, composed of the scores for the four categories. Each category is measured by 47 indicators and sub-indicators. The metrics are based on rescaling the raw data on a scale from 0 to 100 (lowest to highest), giving the scores of a country, and positions from 1 to 35 (highest to lowest), indicating the ranking of a country (European Policies Initiative, 2016).

The World Bank classifies economies under income categories according to the 2015 gross national income (GNI) per capita, calculated using the World Bank Atlas method. The categories are as follows: low income $\$ 1,025$ or less; lower middle income $\$ 1,026$ 4,035; upper middle income $\$ 4,036-12,475$; and high income $\$ 12,476$ or more. The effective IDA eligibility threshold is $\$ 1,185$ or less. According to this, 31 countries were classified as low income, 52 countries were classified as lower middle income, 55 countries were classified as upper middle class, 79 countries were classified as high income and one country (Argentina) was not classified (Table 1) (The World Bank, 2016).

\begin{tabular}{|l|l|}
\hline Low Income & $\$ 1,025$ or less \\
\hline Lower Middle Income & $\$ 1,026-4,035$ \\
\hline Upper Middle Income & $\$ 4,036-12,475$ \\
\hline High Income & $\$ 12,476$ or more \\
\hline
\end{tabular}

Table 1: The World Bank income categories classification.

Source: The World Bank, 2016.

The World Bank classification was used in this study. The classification of the E7 countries and the USA taken as the reference country are tabulated in Table 2. 


\begin{tabular}{|l|l|l|}
\hline Country & $\begin{array}{l}\text { GNI per capita, } \\
\text { Atlas method } \\
\text { (current US\$) }\end{array}$ & Income Classification \\
\hline United States & 54960 & High income \\
\hline Turkey & 9950 & Upper middle income \\
\hline China & 7820 & Upper middle income \\
\hline India & 1590 & Lower middle income \\
\hline Indonesia & 3440 & Lower middle income \\
\hline Mexico & 9710 & Upper middle income \\
\hline Brazil & 9850 & Upper middle income \\
\hline Russia & 11400 & Upper middle income \\
\hline
\end{tabular}

Table 2: Income classification of E-7 countries and USA.Source: The World Bank, 2016.

The E7 (Emerging Seven) is a group of seven countries with emerging economies. The E7 countries are Russia, India, Indonesia, Mexico, Brazil and Turkey. The importance of emerging and developing countries within global economy has been increasing over the course of years. These countries act as catalysts in global economy. According to some projections, the E7 economies will leave behind G7 countries by 2050.

According to the IMF World Economic Outlook (2016), the global output is estimated to have grown by 3,1 \% in 2015. 1,9 \% of this increase comes from advanced economies and $4 \%$ comes from emerging and developing economies.

Table 3 and Figure 1 show that emerging markets and developing countries grow more than the average of global and advanced economies. The situation is also true for the projections made for 2016, 2017 and 2021. Of the E7 countries, the growth rates of China, India and Indonesia are much above the average.

\begin{tabular}{|c|c|c|c|c|c|c|c|c|c|c|c|c|}
\hline & & & & & & & & & & \multicolumn{3}{|c|}{ Projections } \\
\hline & $\begin{array}{l}1998- \\
2007\end{array}$ & 2008 & 2009 & 2010 & 2011 & 2012 & 2013 & 2014 & 2015 & 2016 & 2017 & 2021 \\
\hline World & 4.2 & 3.0 & -0.1 & 5.4 & 4.2 & 3.5 & 3.3 & 3.4 & 3.1 & 3.2 & 3.5 & 3.9 \\
\hline $\begin{array}{l}\text { Advanced } \\
\text { Economies }\end{array}$ & 2.8 & 0.2 & -3.4 & 3.1 & 1.7 & 1.2 & 1.2 & 1.8 & 1.9 & 1.9 & 2.0 & 1.8 \\
\hline $\begin{array}{l}\text { Emerging } \\
\text { Market } \\
\text { and } \\
\text { Developing } \\
\text { Economies }\end{array}$ & 5.8 & 5.8 & 3.0 & 7.4 & 6.3 & 5.3 & 4.9 & 4.6 & 4.0 & 4.1 & 4.6 & 5.1 \\
\hline $\begin{array}{l}\text { United } \\
\text { States }\end{array}$ & 3.0 & -0.3 & -2.8 & 2.5 & 1.6 & 2.2 & 1.5 & 2.4 & 2.4 & 2.4 & 2.5 & 2.0 \\
\hline Russia & 5.8 & 5.2 & -7.8 & 4.5 & 4.3 & 3.5 & 1.3 & 0.7 & -3.7 & -1.8 & 0.8 & 1.5 \\
\hline China & 9.9 & 9.6 & 9.2 & 10.6 & 9.5 & 7.7 & 7.7 & 7.3 & 6.9 & 6.5 & 6.2 & 6.0 \\
\hline India & 7.1 & 3.9 & 8.5 & 10.3 & 6.6 & 5.6 & 6.6 & 7.2 & 7.3 & 7.5 & 7.5 & 7.8 \\
\hline Indonesia & 2.7 & 7.4 & 4.7 & 6.4 & 6.2 & 6.0 & 5.6 & 5.0 & 4.8 & 4.9 & 5.3 & 6.0 \\
\hline Turkey & 4.0 & 0.7 & -4.8 & 9.2 & 8.8 & 2.1 & 4.2 & 2.9 & 3.8 & 3.8 & 3.4 & 3.5 \\
\hline Brazil & 3.0 & 5.1 & -0.1 & 7.5 & 3.9 & 1.9 & 3.0 & 0.1 & -3.8 & -3.8 & 0.0 & 2.0 \\
\hline Mexico & 2.9 & 1.4 & -4.7 & 5.1 & 4.0 & 4.0 & 1.3 & 2.3 & 2.5 & 2.4 & 2.6 & 3.1 \\
\hline
\end{tabular}

Table 3: Real GDP, annual percentage change.

Source: IMF, 2016. 


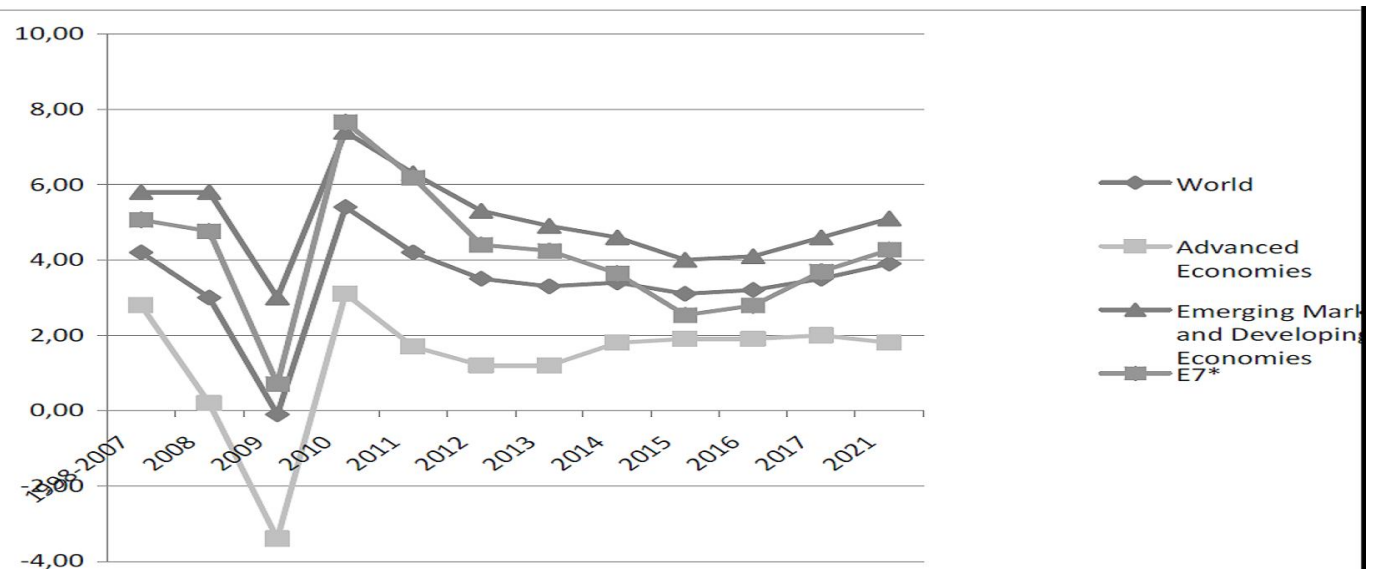

Figure 1: Real GDP, annual percentage change.

*E7 is calculated by the authors. Source: IMF, 2016.

The growth of the E7 countries according to years is given in Figure 2. These countries have been following a growth trend since 1990s and this trend has gained momentum in 2000s. However, they have been following a downward trend since the global crisis in 2008.

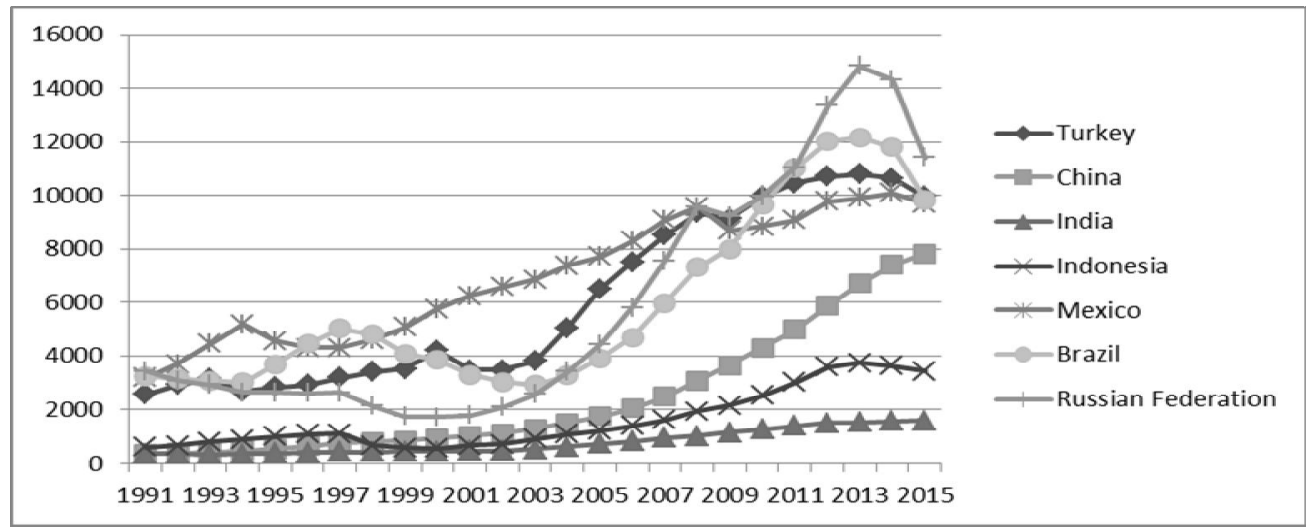

Figure 2: E7 countries GNI per capita, atlas method (current US\$) 1962-2015.

Source: The World Bank Statistics, 2016.

Of the E7 countries, the economic growth of especially China is important. The World Bank (2013) points out to the fact that China's economic performance in the last 30 years has been impressive. The annual average GDP growth is around 10\% and more than 500 million people have been saved from poverty. China is currently the world's largest importer and manufacturer and the second largest economy. If this trend continues in this way, then China will be listed under the high income category before 2030 and will become the world's largest economy.

According to PwC (2015), the G7 group of rich nations will be overtaken by the E7 economies by 2050. Their base case projections point out that the GDP of the E7 countries will be around twice as high as that for the G7 countries by 2050 in PPP terms. According to the report, the E7 countries will continue to be the catalysts of the world economy. The three largest economies of the world will be China, India and the United States 
respectively by 2050. Of the other E7 countries, Indonesia will be the fourth, Brazil the fifth, Mexico the sixth, Russia the eighth and Turkey the fourteenth largest economy in the world by 2050 (Table 4).

\begin{tabular}{|l|l|l|l|}
\hline Country & 2014 & 2030 & 2050 \\
\hline China & 1 & 1 & 1 \\
\hline United States & 2 & 2 & 3 \\
\hline India & 3 & 3 & 2 \\
\hline Japan & 4 & 4 & 7 \\
\hline Germany & 5 & 8 & 10 \\
\hline Russia & 6 & 7 & 8 \\
\hline Brazil & 7 & 6 & 5 \\
\hline France & 8 & 11 & 13 \\
\hline Indonesia & 9 & 5 & 4 \\
\hline United Kingdom & 10 & 10 & 11 \\
\hline Mexico & 11 & 9 & 6 \\
\hline Italy & 12 & 15 & 18 \\
\hline South Korea & 13 & 13 & 17 \\
\hline Saudi Arabia & 14 & 12 & 12 \\
\hline Canada & 15 & 17 & 19 \\
\hline Spain & 16 & 18 & 26 \\
\hline Turkey & 17 & 14 & 14 \\
\hline Iran & 18 & 19 & 25 \\
\hline Australia & 19 & 23 & 28 \\
\hline Nigeria & 20 & 16 & 9 \\
\hline
\end{tabular}

Table 4: GDP at PPP rankings.Source: PwC, 2015.

Despite this growth trend and the economic developments in the E7 countries, none of these countries are under the E7 high income category. The length of stay of the E7 countries under the middle income category is given in Table 5.

\begin{tabular}{|l|l|l|l|l|}
\hline Country & $\begin{array}{l}\text { Number of Years } \\
\text { Spent as a Low } \\
\text { Income Country }\end{array}$ & $\begin{array}{l}\text { Number of Years } \\
\text { Spent as a Lower } \\
\text { Middle Income } \\
\text { Country }\end{array}$ & $\begin{array}{l}\text { Number of Years } \\
\text { Spent as an Upper } \\
\text { Middle-Income } \\
\text { Country }\end{array}$ & $\begin{array}{l}\text { Total Number of } \\
\text { Years Spent as a } \\
\text { Middle-Income } \\
\text { Country }\end{array}$ \\
\hline $\begin{array}{l}\text { Turkey 1967- } \\
2015\end{array}$ & $1967-1975$ & $1975-2004$ & $2004-2015$ & 40 years \\
\hline $\begin{array}{l}\text { China 1962- } \\
2015\end{array}$ & $1962-2002$ & $2002-2010$ & $2010-2015$ & 13 years \\
\hline India 1962-2015 & $1962-2009$ & $2009-2015$ & - & 6 years \\
\hline $\begin{array}{l}\text { Indonesia 1969- } \\
2015\end{array}$ & $1969-1996$ & $1996-2015$ & - & 19 years \\
\hline $\begin{array}{l}\text { Mexico 1962- } \\
2015\end{array}$ & $1962-1974$ & $1974-1993$ & $1993-2015$ & 41 years \\
\hline $\begin{array}{l}\text { Brazil 1962- } \\
2015\end{array}$ & $1962-1975$ & $1975-1996$ & $1996-2015$ & 40 years \\
\hline $\begin{array}{l}\text { Russian Fed. } \\
1991-2015\end{array}$ & $2012-2015$ & $1991-2005$ & $\begin{array}{l}2005-2012 * \\
2015\end{array}$ & 22 years \\
\hline
\end{tabular}

Table 5: The number of years of the E7 countries under the middle-income category (GNI per capita, atlas method (according to the current US\$). *The Russian Federation was classified as a high income country in 2012, 2013 and 2014 but was classified again as an upper middle-income country in 2015. Source: The World Bank Statistics, 2016. 
In the light of these data, it could be said that Turkey was under the low income category between 1967-1975 and the lower middle-income category between 1975-2004. When the per capita income reached 5060 \$ in 2004, Turkey was classified under the upper-middle income category. Turkey has been under the middle income category for the past 40 years.

Although China was ranked under the low income category between 1962-2002 based on GNI per capita, it was ranked under the lower-middle income category between 2002 2010 with a huge jump. As China's per capita income went up to 4,300 \$ in 2010, China is ranked under the middle-income category today.

India used to be under the low income countries category between 1960-2006. India's per capita income reached 1,089 \$ in 2006 and it has been under the lower middle-income countries category since then.

Indonesia was under the low-income countries category between 1962-2009. Its per capita income went up to 1,150 \$ in 2009 and moved up to the lower middle-income category.

Mexico was under the low-income category between 1962-1973 and moved up to and stayed at the lower middle-income category between 1974-1993. When its per capita income reached 4,460 \$ in 1993, it moved up to the upper middle-income category.

Brazil's GNI per capita reached 4, 470 \$ in 1996 and moved up to the upper middleincome category that year. Brazil was ranked as a low income country between 19621975 and as a lower middle-income country between 1975-1996.

The Russian Federation was under the lower middle-income category between 19912005. Entering into a fast growth period after 2005, the GNI per capita went up to 4,450 \$ and the country was ranked under the upper middle-income category between 20052012. The Russian Federation entered in the high income high income category in 2012, 2013 and 2014 and went back (down) to the upper low-income category in 2015.

\section{The Term Middle Income Trap and Literature Review}

The situation of the emerging countries that stay in the middle-income category and that cannot move up to the upper income category for a long period of time is one of the important fields of study for researchers. The term MT was first introduced by Gill et al. (2007) to explain the slowdown of the East Asian miracle economies.

The MIT is the situation whereby an economy is trapped in a certain income level after having reached a certain level of per capita income. The middle income trap is an approach that summarizes the situation of the per capita income not moving any further after having reached a certain income level or the situation of entering into a status of recession after having reached a certain level of income. The term MT is fundamentally based on perceptions of slow growth rates in many middle income countries especially the East Asian and Latin American economies (Ye and Robertsan, 2016).

The World Bank (2013) defines MIT as follows:

“... In the postwar era, many countries have developed rapidly into the middle-income status, but far fewer have gone on to high-income status. Rather, they have become stuck in the so-called middle-income trap. The factors and advantages that propelled high growth in these countries during their rapid development phases-low-cost labor and easy technology adoption-disappeared when they reached middle- and upper-middleincome levels, forcing them to find new sources of growth."

Ohno (2010) defined five stages of industrialization: Stage zero (pre-industrialization), stage one (initial FDI absorption), stage two (internalizing parts and components), stage three (internalizing skills and technology) and stage four (internalizing innovation). There 
is an invisible glass between these two stages and the MIT is defined as the situation of failing to go up/ jump up from Stage Two to Stage Three.

Ohno (2010) noted that development must come from the upgrading of human capital rather than natural resources, geographical advantage or foreign aid and investment. Ohno also defined "developmental trap" as follows: "Depending on the amount of these unearned advantages, a country may rise to a low, middle or high income level with little effort but will eventually get stuck in that income category if it fails to build a national mindset and the institutions that encourage constant upgrading of its human capital."

Felipe, Abdon and Kumar (2012) explained MIT as "countries unable to compete with low-income, low-wage economies in manufactured exports and with advanced economies in high-skill innovations...such countries cannot make a timely transition from resourcedriven growth, with low cost labor and capital, to productivity-driven growth."

According to Lee and Narjoko (2015), "MTT has been used to characterize a situation in which middle income countries experience economic slowdown or stagnation, which prevents them from graduating into high income countries".

Paus (2012) used the term to explain a situation where middle income economies cannot compete with low income countries in the export of standardized products and those countries have, in addition, not devoloped the capabilities to compete in the exports of skill and knowledge based goods and services.

According to the World Bank Report (2013), many economies in the Latin America and the Middle East joined in the middle-income category at the beginning of 1960s and 1970s. Only 13 out of 101 economies that were classified as middle-income countries in the 1960s achieved to be granted the high income status in 2008 (Equatorial Guinea, Greece, Hong Kong SAR, China, Ireland, Israel, Japan, Mauritius, Portugal, Puerto Rico, Republic of Korea, Singapore, Spain, Taiwan and China).

The problem of under which conditions an income level should be accepted as an MT has been addressed in many studies. Various approaches have been put forward to identify whether a country has fallen into the middle-income trap.

When the middle-income trap approach was first mentioned, 20 percent of GNI per capita in the USA was accepted as middle-income for economies. Assuming that GNI per capita was roughly 50,000 in the USA, then 10,000 \$, i.e. 20 percent of GNI per capita, was accepted as middle-income.

MIT is the situation whereby the middle-income countries and/ or regions that have reached the required GNI per capita are stuck in a given income band and cannot move up to a higher income level. The per capita being trapped within the band of 15 - 16 thousand $\$$ and/or cannot go over $58 \%$ of GNI per capita are the quantitative indicators of the middle income trap (Yeldan et al., 2013).

Eichengreen, Park and Shin (2013) analyzed the conditions under which fast-growing middle-income economies fall into the MT. The study they carried out in 2012 indicated to the existence of a single mode at which slowdowns occur at about $\$ 15.000-\$ 16.000$ according to 2005 purchasing power parity in dollars. In the light of the analysis in their new study, new data point to two modes, one in the $\$ 10,000-\$ 11,000$ range and another at $\$ 15,000-\$ 16,000$.

Many developing countries have experienced spurts of rapid economic growth. It is thanks to these growth figures that emerging economies have started to close down the income gap between developed economies and emerging economies and economics convergence has been achieved within these two categories of countries. However, especially after the 2008 financial crisis, the speed of income convergence has been modest. Such a situation, i.e. the low trend of growth and slow or non-existent convergence, is defined as MIT (Staehr, 2013). 
There are numerous studies in literature that focus on identifying the MIT based on various statistics and/ or econometric models, the sources that lead countries into the MIT and their impact on MIT. Some of these studies are descriptive or empirical and some focus on single countries whereas some focus on country categories.

Felipe, Abdon and Kumar (2012) calculated the threshold number of years for a country to be in the MIT. Threshold was found to be 28 years for lower-middle income countries and 14 years for upper-middle income countries. The countries with GNI per capita of 2000-7250 \$ were categorized as lower middle-income countries and the countries with a GNI per capita of 7,250-11,750 \$ were categorized as upper middleincome countries. They pointed that lower middle-income countries have to attain an average growth rate of per capita income of at least $4.7 \%$ to reach upper middle-income category. This ratio is 3,5\% per annum for upper-middle income economies to avoid falling into MIT.

Felipe, Abdon and Kumar (2012) found out that 35 out of 52 countries were in MIT. 30 of them were in the lower middle-income category and 5 were in the upper middleincome category 2 .

Öztürk (2016) conducted an analysis on the economics development of emerging markets and found that there were 11 emerging markets that had stayed in the middleincome stage over 33 years and facing the pressure of middle income trap. According to study, the countries remained in the middle- income category between 1980 and 2012 were Argentina, Croatia, Czech Republic, Estonia, Hungry, Lithuania, Mexico, Poland, Portugal, Turkey and Venezuela.

The World Bank report by Gill et al. (2007) stated that the middle-income East Asian countries were in the middle income trap and solutions were offered to get out of the middle income trap. According to the report, Latin America and the Middle East were examples of middle-income regions that, for decades, have been unable to escape this trap.

Eichengreen, Park and Shin (2013) analyzed historical growth slowdowns in emerging economies. They examined post-1956 cases of fast-growing countries. The annual average GDP per capita growth was around 3,5\% for seven and more years. However, these growth figures went down in later periods. The GDP per capita went down by at least two percent between successive seven years period. This study investigated the reasons of this slowdown period. It was found out that structural changes on factors such as human capital, political regime changes, external factors, technology content of exports and financial instability have got an impact on MIT.

Kasjanovs (2015) analyzed whether the Latvian economy was in MIT. By studying various variables of the Latvian economy such as export share, profitability ratios of Latvian companies and the level of remuneration gap in the area, it was concluded in the study that the Latvian economy would fall in the MIT in the future.

Robertson and Ye (2013) analyzed the existence of the MIT in the middle income countries by using the Augmented Dickey Fuller unit root test. Their sample included countries having $8 \%-36 \%$ of the U.S. per capita GDP ( 46 out of 189 countries are middle

\footnotetext{
${ }^{2}$ Economies in the lower middle-income trap are Phillippines, Sri Lanka, Albania, Romania, Bolivia, Brazil, Colombia, Dominican Republic, Ecuador, El Salvador, Guatemala, Jamaica, Panama, Paraguay, Peru, Algeria, Egypt, Iran, Jordan, Lebanon, Libya, Morocco, Tunusia, Yemen, Botswana, Congo, Gabon, Namibia, South Africa and Swaziland.

Economies in the upper middle-income trap are Malaysia, Uruguay, Venezuela, Saudi Arabia, Syria.
} 
income countries). Based on this, they made a list of 37 suspected MT countries, from a total of 46 .

In another study, Ye and Robertson (2016) developed a time series test of MIT and applied it to 46 middle-income countries. They found that seven countries (Cuba, Lebanon, Turkey, El Salvador, Thailand, Peru and Syria) were candidates to be in the MIT. Staehr (2013) investigated whether the Baltic countries (Estonia, Latvia and Lithuania) have fallen into the MT. According to the study carried out based on interpreting various macro statistics, the countries have seen rapid economics and increasing living standards, but the convergence process slowed down after the global financial crisis, and the possibility of a MT cannot be ruled out.

Koçak and Bulut (2014) examined whether the Turkish economy is in the middle income trap by using the approach introduced by Robertson and Ye (2013). According to the results of the unit root tests, the Turkish economy is not in the middle-income trap.

\section{Data, Econometric Methods and Results}

The GNI per capita and the Atlas method (current US\$) data of the World Bank were used for the period 1969-2015. The USA has been the economic leader of the world since 1920s. As a result of the continuous upward trend of the USA in economic growth and the demand for GNI per capita, it has become a generally accepted approach to compare the income levels of countries against to that of the USA. Therefore, the USA has been considered as a reference wealthy economy that has been growing in a balanced fashion in this study (Figure 3). Of the E7 countries, Russia was not included in the study as it was necessary to include the same period for all countries in the study.

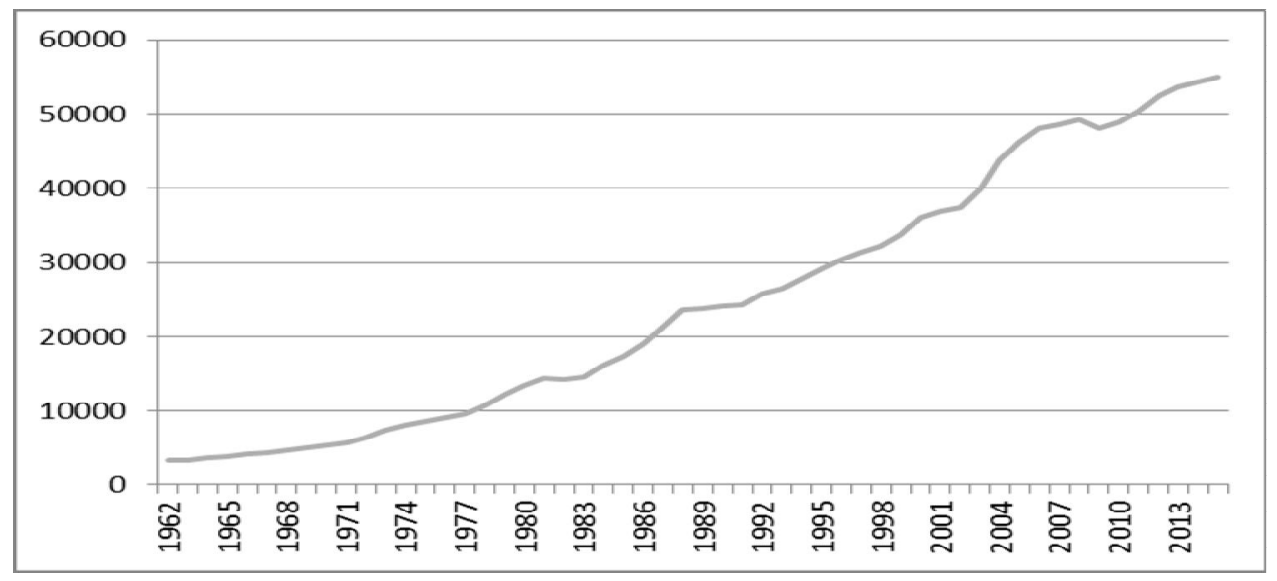

Figure 3: United States GNI per capita, atlas method (current US\$) 1962-2015. Source: The World Bank Statistics, 2016.

The following Robertson and Ye (2013) data set has been arranged as

$$
y_{t}=\ln \left(\frac{G D P_{A, t}}{G D P_{A B D, t}}\right) \text {. }
$$

$G D P_{A, z}$ indicates the GNI per capita, atlas method of Country A and $G D P_{A B D, t}$ indicates GNI per capita, atlas method of the USA. 
According to Robertson and Ye (2013) approach, when unit root null hypothesis is rejected (Ho non stationary hypothesis is rejected), the countries are in the middle income trap if they also agree with the second condition (expected value of the ratio within the limits of middle income definition).

In Table 5, the ratio of GNI per capita of each country of E7 with the USA have been presented.

Table 5: The ratio of GNI per capita of each country of E7 with the USA for 1969 and 2015 years.

\begin{tabular}{|l|c|c|c|c|}
\hline $\begin{array}{l}\text { E7 } \\
\text { Countries }\end{array}$ & $\begin{array}{c}\text { Gni } \\
\text { RATI0 } \\
\mathbf{6 9}\end{array}$ & $\begin{array}{c}\text { Gni } \\
\text { RATIO } \\
\mathbf{2 0 1 5}\end{array}$ & $\begin{array}{c}\mathbf{1 9 6 9} \\
\text { Ln(X) }\end{array}$ & $\begin{array}{c}\mathbf{2 0 1 5} \\
\text { Lon(X) }\end{array}$ \\
\hline Turkey & 0.1105 & 0.1810 & -2.2031593 & -1.7090331 \\
\hline China & 0.0217 & 0.1423 & -3.8306157 & -1.9499211 \\
\hline India & 0.0217 & 0.0289 & -3.8306157 & -3.5428716 \\
\hline Indonesia & 0.0158 & 0.0626 & -4.1490695 & -2.7711342 \\
\hline Mexico & 0.1243 & 0.1767 & -2.0853763 & -1.7334494 \\
\hline Brazil & 0.0809 & 0.1792 & -2.5149389 & -1.7191342 \\
\hline
\end{tabular}

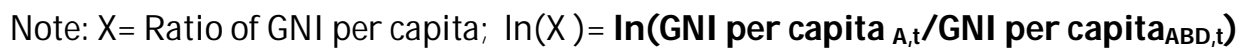

In the period 1969-2015 there was important increase of GNI per capita in several of these countries. While the United States almost increased in 100\% its real value of GNI per capita, several of these countries experienced highest percentages of increase and it resulted in an increase of the ratio $\mathrm{X}$. The have advanced many point in the middle income interval. The highest increase of the ratio, for the period 1969-2015 among the countries of table 5, corresponded to China from 0.0217 to 0.1423 . Outstanding increases also corresponded to Brazil (from 0.0809 to 0.1792 ) and to Turkey (0.1105 to 0.1810). Important but more moderate increases where those of Indonesia( from 0.0158 to 0.062 ) and Mexico (from 0.1243 to 0.1767). India has experienced a very small increase in the ratio for the period 1969-2015.

Several interesting explanations about the different economic policies of developing countries, regarding the role of industrialization and investment have been analyzed in Guisan(2017) and in other studies.

In Annexes A1 y A2, we present the results of Unit Root tests and Panel Unit Root tests, in order to test stationarity.

\section{Empirical Results}

This study investigates the middle income trap in E7 countries and the analyses are going to be carried out by using univariate and panel unit root tests in both linear and nonlinear forms. Of the univariate linear unit root tests, the ADF and $\mathrm{Ng}$-Perron tests were primarily used and the results are presented in Table 6 in Panel A. According to results, there is stationarity in Brazil and Mexico. Panel B tabulates the test results for KSS, Kruse, Sollis and CHLL nonlinear unit root tests. According to these results, the Kruse test is stationary only for Mexico; however one cannot talk of stationarity for other countries. 


\begin{tabular}{|c|c|c|c|c|c|c|}
\hline \multicolumn{3}{|c|}{ Panel A: Linear Unit Root Tests } & & & & \\
\hline & $\mathrm{ADF}$ & \multicolumn{4}{|l|}{ Ng-Perron } & \\
\hline & Test Stat & MZa & MZt & MSB & MPT & \\
\hline BRA & $-4.51633^{a}$ & $-137.597 a$ & $-8.29225^{a}$ & $0.06026^{\mathrm{a}}$ & $0.66952^{\mathrm{a}}$ & \\
\hline $\mathrm{CHN}$ & -0.889061 & -4.03115 & -1.21666 & 0.30181 & 20.3706 & \\
\hline IDN & -2.498323 & -13.2148 & -2.54183 & 0.19235 & 7.05743 & \\
\hline IND & -0.606329 & -9.48832 & -2.03754 & 0.21474 & 10.177 & \\
\hline MEX & 0.099245 & $-31.0813^{a}$ & $-3.94208^{a}$ & $0.12683^{a}$ & $2.93229^{a}$ & \\
\hline TUR & -2.301515 & -11.3449 & -2.3617 & 0.20817 & 8.13519 & \\
\hline \multicolumn{7}{|c|}{ Panel B: Nonlinear Unit Root Tests } \\
\hline & KSS & Kruse & \multicolumn{2}{|l|}{ Sollis } & & \\
\hline & Test Stat & Test Stat & Test Stat & A.Test Stat & & \\
\hline BRA & -1.734525 & 4.38482 & 4.658253 & 1.293306 & & \\
\hline $\mathrm{CHN}$ & -1.599803 & 1.37994 & 1.495385 & 0.464809 & & \\
\hline IDN & -2.281244 & 2.543491 & 2.586128 & 0.079577 & & \\
\hline IND & -1.437237 & 1.21666 & 1.481254 & 0.901804 & & \\
\hline MEX & -2.176724 & $12.37063 \mathrm{c}$ & 5.234164 & $5.240187 \mathrm{~b}$ & & \\
\hline \multirow[t]{3}{*}{ TUR } & -2.543196 & 3.462727 & 3.439235 & 0.487686 & & \\
\hline & \multicolumn{3}{|c|}{ CHLL (Trend) } & \multicolumn{3}{|c|}{ CHLL (Trend2) } \\
\hline & Test Stat & Trend Coef. & Trend t-stat & Test Stat & Trend ${ }^{2}$ Coef. & Trend $^{2}$ t-stat \\
\hline BRA & -1.700586 & -0.001266 & -1.334114 & -1.321479 & $-1.65 \mathrm{E}-05$ & -0.810937 \\
\hline $\mathrm{CHN}$ & 1.571325 & 0.001818 & $2.764304^{a}$ & 0.611756 & $3.97 \mathrm{E}-05$ & $2.616356^{b}$ \\
\hline IDN & -1.279667 & -0.000593 & -0.600342 & -1.127101 & $-4.57 \mathrm{E}-06$ & -0.202861 \\
\hline IND & 0.391641 & 0.000527 & 0.720519 & 0.412633 & $1.46 \mathrm{E}-05$ & 1.002827 \\
\hline MEX & -1.188633 & -0.000522 & -0.765647 & -1.053178 & $-7.69 \mathrm{E}-06$ & -0.507238 \\
\hline TUR & -1.109824 & -0.000391 & -0.505674 & -1.029062 & $-3.88 \mathrm{E}-06$ & -0.222799 \\
\hline
\end{tabular}
$\mathrm{a}, \mathrm{b}, \mathrm{c}$ Indicate

Table 6: Linear and nonlinear univariate unit root tests.

The analyses were carried out by using linear and nonlinear panel unit root tests in order to increase the reliability of the results obtained in the second phase of the study and the results are tabulated in Table 7.

\begin{tabular}{|l|l|l|}
\hline Panel A: Linear Panel Unit Root Tests & & \\
\hline & Test Stat & \\
\hline Im, Pesaran and Shin & -0.79095 & \\
\hline Levin, Lin and Chu & -0.88 & \\
\hline Demetrescu and Hanck(2012) $\mathrm{m}=0$ & -2.08296 & \\
\hline Demetrescu and Hanck(2012) $\mathrm{m}=1$ & -1.12282 & \\
\hline Demetrescu and Hanck(2012) $\mathrm{m}=2$ & 1.26601 & \\
\hline Panel B: Nonlinear Panel Unit Root Tests & & \\
\hline & Test Stat & $\mathrm{p}$ value \\
\hline Emirmahmutoğlu and Omay(2014) & 3.907 & 0.428 \\
\hline Uçar and Omay(2009) & -2.05 & 0.739 \\
\hline
\end{tabular}

Table 7: Linear and nonlinear panel unit root tests. 
Panel A of Table 7 shows the nonstationarity according to the Im, Pesaran and Shin, Levin, Lin and Chu and Demetrescu and Hanck test results which are linear panel unit root tests. Panel B shows the tests results of the Emirmahmutoğlu and Omay, Uçar and Omay nonlinear panel unit root tests. The results of relevant tests indicate nonstationarity.

When the results of both univariate and panel linear and nonlinear unit root tests are assessed together, it is seen that the series are not stationary. This finding indicates that there is no MIT in E7 countries.

\section{Conclusion}

There is no absolute explanation, determinant or reason, and solution for avoiding or overcoming of MIT. However, MIT could be defined as the countries under the middle income category based on GNI per capita failing to surpass this level and becoming part of the high income countries category.

All of the E7 countries that have been making significant economic progress since 1990s are under the middle income category according to the World Bank classification. Despite their high economic performances, they are in the middle income category.

Given their important positions in global economy, it is important to identify the presence of MT in these countries. The univariate and panel unit root tests were used in linear and nonlinear forms and when the test results were examined all together, the series are not stationary. It was found in the study E7 countries did not fall into the MIT.

These results indicate that although the E7 countries were under the middle income category for long years according to the World Bank classification, it also indicates that the conditions for MIT have not developed in these countries. In order to talk of MIT, there needs to be modest growth and slow convergence. Such a trap could cause coordination problems among different players and decrease in productive capacity growth. If that is the case, then one cannot talk of the transition of the E7 countries from Stage Two to Stage Three as Ohno (2010) indicated. There is also no decrease in the productive capacity growth trend. For this reason, these countries have not experienced economic slowdown or stagnation.

Accordingly to table 5, we may notice that there are strong differences regarding the evolution of the ratio of Gross Domestic Product per capita of E7 countries: while some of them have experienced high increases (China from 0.0217 to 0.1423 , Turkey from 0.1105 to 0.1810 and Brazil from 0.0809 to 0.1792 ) other ones has experienced moderate increases (Indonesia from 0.0158 to 0.0626 and Mexico from 0.1243 to 0.1767 ) and in the case of India there has been almost stagnation of the ratio (from 0.0217 to 0.0289 ).

\section{References}

Anoruo, E., and V.N.R. Murthy (2014). Testing nonlinear inflation convergence for the Central African Economic and Monetary Community. Int. J. Econ. Financ Issues 4(1), 1-7.

Bahmani-Oskooee, M., and S.W Hegerty (2009). Purchasing power parity in lessdeveloped and transition economies: a review paper. Journal of Economic Surveys 23(4), 647-658.

Chang, Y. (2004). Bootstrap unit root tests in panels with cross-sectional dependency. Journal of Econometrics 120, 263-293.

Chong, T. T. L., M. J. Hinich, , V. K. S. Liewand, and K. P. Lim (2008). Time series test of nonlinear convergence and transitional dynamics. Economics Letters, 100(3), 337-339.

Cuestas, J.C., and C. Ramlogan-Dobson(2013). Convergence of inflationary shocks 
: evidence from the Caribbean. The World Economy, 36(9), 1229-1243.

Cuestas, J.C., and D. Garratt (2011). Is real GDP per capita a stationary process? smooth transitions, nonlinear trends and unit root testing. Empirical Economy. 41, 555-563.

Dash, A. K., and A. K. Tiwari (2015). Are tourist arrivals stationary? Evidence from BRIC countries. Current Issues in Tourism, 1-4.

Demetrescu, M., and C. Hanck (2012). Unit root testing in heteroscedastic panels using the Cauchy estimator. Journal of Business \& Economic Statistics, 30(2) , 256-264.

Dickey, D. A., and W. A. Fuller (1979). Distribution of the estimators for autoregressive time series with a unit root. Journal of the American statistical association, 74(366a), 427 431.

Dickey, D. A., and W. A. Fuller (1981). Likelihood ratio statistics for autoregressive time series with a unit root. Econometrica: Journal of the Econometric Society, 1057-1072.

Eichengreen, B., D. Park and K. Shin (2013). Growth slowdown redux: new evidence on the middle income trap. NBER Working Paper Series No. 18673, January 2013.

Emirmahmutoglu, F., and T. Omay (2014). Reexamining the PPP hypothesis: A nonlinear asymmetric heterogeneous panel unit root test. Economic Modelling 40, 184-190.

European Policies Initiative (2016). State of the Union: findings of the European catch-up index. http:/ / eupi.osi.bg/ fce/ 001/ 0066/ files/Summary_CatchUpIndex_c.pdf （accessed 01.07.2016).

Felipe, J., A. Abdon, and U. Kumar (2012). Tarcking the middle-income trap: What is it, Who is in it, and why?, Levy Economics Institute of Bard College, Working Paper No. 715, 159 .

Gill, I., H. Kharas, D. Bhattasali, M. Brahmbhatt, G. Datt, M. Haddad, E. Mountfield, R. Tatucu, E. Vostroknutova. (2007). An East Asian reneissance, ideas for economics growth. The International Bank for Reconstruction and Development/ The World Bank.

Guisan, M.C. (2017). Manufacturing And Economic Development In The World For 20002015: Main Features And Challenges, Revista Galega De Economia, Vol. 26-3.1

Im, K. S., H. Pesaran, and Y. Shin (2003). Testing for unit roots in heterogeneous panels. Journal of Econometrics 115, 53-74.

IMF (2016). World economic outlook, too slow for too long.

Kapetanios, G., Y. Shin, and A. Snell (2003). Testing for a unit root in the nonlinear star framework. Journal of Econometrics 12, 359-379.

Kasjanovs, I. (2015). Is part of the Latvian economy already in the middle-income trap?.

World Economics, vol. 16, issue 1, 58-69.

Koçak, E. and Ü. Bulut (2014). Orta gelir tuzağı: teorik çerçeve, ampirik yaklaşımlar ve Türkiye üzerine ekonometrik bir uygulama, Maliye Dergisi, No. 167, 1-21.

Kruse, R. (2011). A new unit root test against ESTAR based on a class of modified statistics. Stat. Pap. 52, 71-85.

Lee, C., and D. Narjoko (2015). Escaping the middle-income trap in Southeast Asia: micro evidence on innovation, productivity, and globalizatin. Asian Economic Policy Review, 10, 124-147.

Levin, A., C. Lin, and C. J. Chu (2002). Unit root tests in panel data: asymptotic and finite sample properties. Journal of Econometrics 108, 1-24. 
Ng, S., and P. Perron (2001). Lag length selection and the construction of unit root tests with good size and power. Econometrica, 69(6), 1519-1554.

Ohno, K. (2010). Avoiding the middle income trap: renovating industrial policy formulation in Vietnam. Expanded and updated version of the paper originally published in the ASEAN Economic Bulletin, vol. 26, no.1, 25-43.

Öztürk, A. (2016). Examing the economics growth and middle-income trap from the perspective of the middle class. International Business Review 25, 726-738.

Paus, E. (2012). Confronting the middle income trap: Insights from small latecomers, St Comp Int. Dev. 47, 115-138.

Perron, P. (1989). The great crash, the oil price shock, and the unit root hypothesis. Econometrica: Journal of the Econometric Society, 1361-1401.

PwC (2015). The world in 2050, will the shift in global economy power continue?. http:/ / www.pwc.com/ gx/ en/ issues/ the-economy/ assets/ world-in-2050-february2015.pdf (accessed, 01.06.2016).

Robertson, P., E., and L. Ye (2013). On the existence of a middle income trap. Available at SSRN:http:/ / ssrn.com/abstract=2227776 or http:// dx.doi.org/ 10.2139/ssrn.2227776 (accessed, 05.07.2016).

Sollis, R. (2009). A simple unit root test against asymmetric star nonlinearity with an application to real exchange rates in NORDIC countries. Economic Modelling 26, 118-125.

Staehr, K. (2013). Economic growth and convergence in the Baltic states: caught in a middle-income trap?. Intereconomics, Volume 50, Issue 5, 274-280.

The World Bank (2013). China 2030: building a modern, harmonious, and creative society. Development Research Center of the State Council, the People's Republic of China.

The World Bank (2016). Country and lending groups. https:/ / datahelpdesk.worldbank.org/ knowledgebase/ articles/906519 ～(accessed 15.07.2016).

The World Bank Statistics 2016.

Uçar, N., and T. Omay (2009). Testing for unit roots in nonlinear heterogeneous panels. Economics Letters 104, 5-8.

YE, L., and P. E. Robertson (2016). On the existance of middle-income trap, Economic Record, Vol. 92, No. 297, 173-189.

Yeldan, E., K. Taşçı, E. Voyvada, M. E. Özsan (2013). Orta gelir tuzağından çıkış: hangi Türkiye?. Cilt 2: Bölgesel Kalkınma ve Íkili Tuzaktan Çıkış Stratejileri, Türkfonfed.

${ }^{1}$ Revista Galega de Economia, downloadble at: http:/ / www.usc.es/ econo/ RGE.benvidag.htm

Annexes on line at the journal Website and at: https:/ ideas.repec.org/ s/ sdo/ regaec.html 


\section{Annex 1. Univariate Unit Root Tests}

The stationarity of the time series analysis was investigated by using the unit root tests. The unit root tests were first introduced in literature by Dickey and Fuller (1979). Perron's study (1989) introduced fundamental changes in the unit root test process. This study showed that the presence of a structural breakdown yields results that do not tend to be stationary in conventional unit root tests. A similar situation exists also in nonlinearity. If the data are nonlinear, then the linear unit root tests will face the problem of power. These test results will be biased towards the non-rejection of the null hypothesis (Cuestas and Garrant 2011). The situation mentioned for univariate unit root tests is also valid for panel unit root tests.

Out of the univariate unit root tests, the Augmented Dickey Fuller (ADF) (1981) test and the Ng-Perron (2001) tests will be used first in the study.

Traditional unit root tests cause three problems:

- If equation roots are close to 1 , then the tests have got low power,

- If the moving average structure is negative, then this causes sampling size distortion,

- Since lag length will be influenced size distortion, the test will have low power.

The Ng-Perron (2001) test was chosen as it eliminates such problems. Of the nonlinear unit root tests, the tests by Kapetanios, Shin and Snell (2003), Kruse (2011), Sollis (2009) and Chong, Hinich, Liew vand Lim (2008) will be used in the later phases of the study.

The Kapetanios et al. (2003) nonlinear unit root test, which is based on the smooth transition autoregressive (STAR) methodology and is considered a nonlinear version of the linear Augmented Dickey Fuller (ADF) test, was used to test for nonlinear stationarity (Bahmani-Oskooee and Hegerty, 2009; 644).

Kapetanios et al. (2003) provide an alternative framework for a test of the null of a unit root process against an alternative of nonlinear exponential smooth transition autoregressive (ESTAR) process, which is globally stationary.

ESTAR model is as follows:

$$
y_{t}=\beta y_{t-1}+\gamma y_{t-1}\left[1-\exp \left\{-\theta\left(y_{t-1}-c\right)^{2}\right\}\right]+\varepsilon_{t}
$$

The authors make the restriction $\mathrm{c}=0$ and consider the following model:

$$
\Delta y_{t}=\phi y_{t-1}+\gamma y_{t-1}\left[1-\exp \left\{-\theta y_{t-1}^{2}\right\}\right]+\varepsilon_{t}
$$

in which $\phi=\beta-1$. In the above equation, if $\theta$ is positive, it effectively determines the speed of mean reversion. Kapetanios et al. (2003) demonstrate in case of $\phi=0$ specific ESTAR model as,

$$
\Delta y_{t}=\gamma y_{t-1}\left[1-\exp \left(-\theta y_{t-1}^{2}\right)\right]+\varepsilon_{t}
$$

In test procedures, specific parameter $\theta$, which is zero under the unit root null hypothesis $\left(H_{0}: \theta=0\right)$ and positive under the globally stationary ESTAR alternative hypothesis $\left(H_{1}: \theta>0\right)$. Testing the null hypothesis directly is not feasible, $\gamma$ is not identified under the null. To overcome this problem, the t-type test statistics were developed. They demonstrate a first-order Taylor series approximation to the ESTAR model under the null and the auxiliary regression.

$$
\Delta y_{t}=\delta y_{t-1}^{3}+\text { error }
$$


They obtain the t-statistic for $\delta<0$ against $\delta<0$ as $t_{N L}=\hat{\delta} /$ s.e. $(\hat{\delta})$ where $\hat{\delta}$ is the OLS estimate of $\delta$ and s.e. $(\hat{\delta})$ is the standard error of $\hat{\delta}$. Kapetanios et al. (2003) obtained the asymptotic critical value of $t_{N L}$ statistics for three cases in their study.

Kruse (2011) suggests that the zero location parameter $\mathrm{c}$ is too restrictive. The aim of this new test is to obtain a unit root test that permits a nonzero location parameter $\mathrm{c}$ and that can compete with the extant one of Kapetanios et al. (2003) in terms of size and power. Kruse (2011) has shown that in real world examples, the possibility of non-zero location parameter is imminent. For that reason, they extend the Kapetanios et al. (2003) nonlinear unit root test to allow for a nonzero location parameter. In time series econometrics literature, this test is called the Kruse tau test (Anoruo and Murthy, 2014).

The Kruse (2011) test allows for nonzero location parameter c in the exponential transition function and considers the nonlinear time series model as:

$$
\Delta y_{t}=\phi y_{t-1}\left(1-\exp \left\{-\gamma\left(y_{t-1}-c\right)^{2}\right\}\right)+\varepsilon_{t}
$$

Afterwards, following the Kapetanios et al. (2003) test procedures, a first order Taylor approximation to $G\left(y_{t-1} ; \gamma, c\right)=\left(1-\exp \left\{-\gamma\left(y_{t-1}-c\right)^{2}\right\}\right)$ around $\gamma=0$ and proceed with the test regression. Using this piece of information, the test equation could be written as follows:

$$
\Delta y_{t}=\beta_{1} y_{t-1}^{3}+\beta_{2} y_{t-1}^{2}+\beta_{3} y_{t-1}+u_{t}
$$

They impose $\beta_{3}=0$ to improve the power of the test and proceed with

$$
\Delta y_{t}=\beta_{1} y_{t-1}^{3}+\beta_{2} y_{t-1}^{2}+u_{t}
$$

where $\beta_{1}=\gamma \phi$ and $\beta_{2}=-2 c \gamma \phi$. The null and alternative hypotheses are $H_{0}: \beta_{1}=\beta_{2}=0, H_{1}: \beta_{1}<0, \beta_{2} \neq 0$, respectively.

The two sidedness of $\beta_{2}$ under $H_{1}$ stems from the fact that $\mathrm{c}$ is allowed to take real values. The standard Wald test statistics developed by Kruse (2011) based on the Hessian matrix is simply formulated as

$$
\tau=t_{\beta_{2}^{\perp}=0}^{2}+1\left(\hat{\beta}_{1}<0\right) t_{\beta_{1}=0}^{2}
$$

They obtain asymptotic critical value based on 20000 replications with the Monte Carlo study. The results of the Monte Carlo study show that the new unit root test is in most situations superior to the extant test (Kruse, 2011).

The KSS test is based on the assumption that mean reversion is symmetrical at every point. This assumption means that both negative and positive deviations have got the same impact. Sollis (2009) developed a new procedure that allows for symmetrical or asymmetrical nonlinear adjustments by extending the scope of this assumption. In this test, the speed of mean reversion will be different depending on the sign of the shock, not only the size (Cuestas and Ramlogan-Dobson 2013). The model to be used for the test based on the AESTAR model proposed by Sollis (2009) is as follows:

$$
\Delta y_{t}=\phi_{1} y_{t-1}^{3}+\phi_{2} y_{t-1}^{4}+\sum_{i=1}^{k} k_{i} \Delta y_{t-i}+\eta_{i}
$$


As it is the case with the KSS test, $y_{t}$ is raw data, demeaned data or detrended data. The null hypothesis of nonstationarity is $H_{0}: \phi_{1}=\phi_{2}=0$. The critical values of $\mathrm{F}$ statistics were tabulated by Sollis (2009). When the null hypothesis is rejected, the null hypothesis of symmetric ESTAR, $H_{0}: \phi_{2}=0$, can be tested against the alternative of asymmetric ESTAR, $H_{0}: \phi_{2} \neq 0$, by means of astandard hypotheses test. For standard F critical values to be applicable for this test, $\phi_{1}<0$, so that under the null being tested the series is stationary (Sollis 2009).

The test developed by Chong, Hinich, Liew and Lim (2008) is a nonlinear unit root test. This test is an extended form of unit root test developed by KSS. The test is different from the KSS test as it was developed by adding the cutting parameter and the trend to the model to be used in the unit root test. It is, thus, possible to make the differentiation between the convergence and catching up hypotheses. The equation to be used for the test is as follows:

$$
\Delta y_{t}=\mu+\phi G(\text { Trend })+\delta y_{t-1}^{3}+\sum_{j=1}^{p} p_{j} \Delta y_{t-j}+\xi_{t}
$$

$y_{t}$ is the original series to be examined and $G($ Trend $)$ is the trend variable and this variable can be in different forms. The trend variables used frequently are linear trend and nonlinear trend variables. The null hypothesis for nonstationarity is $H_{0}: \delta=0$ and the alternative hypothesis is for stationarity is $H_{1}: \delta<0$.

The test statistics is the test statistics of the $\delta$ parameter as it is the case with the conventional ADF test mentality. Critical values are tabulated in the study by Chong, Hinich, Liew and Lim (2008).

\section{Annex 2. Panel Unit Root Tests}

In order to increase the reliability of the results obtained in the study, the linear and nonlinear panel unit root tests were used in addition to the univariate unit root tests. The Im, Peseran and Shin (2003) test and the Levin, Li, Chiu (2002) test which are frequently used in practical work as the linear panel unit root test were used. In addition, the panel unit root test introduced to literature by Demetrescu and Hanck (2012) is going to be used. The main advantage of this test is that it is more powerful in places where the panel size is small.

The Demetrescu and Hanck (2012) test model which assumes cross section dependence is as follows:

$\Delta y_{i, t}=\alpha_{i}+\phi_{i} y_{i, t-1}+\sum_{k=1}^{\rho_{\mathrm{i}}} \beta_{i, k} \Delta y_{i, t-k}+e_{i, t}$

Where $e_{t, t}$ is the error term and $i=1, \ldots . . N$, and $t=1, \ldots . \mathrm{T}$. The null and alternative hypotheses are $H_{0}: \phi_{i}=0$ for all $\mathrm{i}=1 \ldots \mathrm{N}$ and $\boldsymbol{H}_{0}: \phi_{i}<0$ for all $\mathrm{i}=1 \ldots \mathrm{N}$, respectively. The alternative hypothesis allows unit roots for some (but not all) of the countries.

Demetrescu and Hanck (2012) suggested a test for small panel using instrument variable Cauchy estimator. Demetrescu and Hanck (2012) has shown that instrument variable t type statistics follows a standard normal distribution (Dash and Tiwari, 2015). 
The nonlinear panel unit root tests by Uçar and Omay (2009) and Emirmahmutoğlu and Omay (2014) are going to be used in the last phase of the study.

The Uçar and Omay (2009) test is a version of the Kapetanios et.al.(2003) test developed for panel data. Uçar and Omay (2009) consider $y_{i t}$ generated by panel exponential smooth transition autoregressive process together with fixed effect parameter $\alpha_{i}$. This model can be shown as follows: $t=1,2, \ldots .$. T shows the time domain and $i=1,2, \ldots . . \mathrm{N}$ shows the cross section units. $d \geq \mathbf{1}$ is a delay parameter and $\theta_{i} \geq 0$ represents the speed of reversion for all units, $\varepsilon_{i \underline{t}}$ is a serially and cross-sectionally uncorrelated distrubance term with zero mean and variance $\sigma_{i}^{2}$.

As it is the case with Kapetanios et.al.(2003), when the Taylor series approximation is used, the model is going to look like the following:

$\Delta y_{i t}=\alpha_{i}+\delta_{i} y_{i t-1}^{3}+\varepsilon_{i t}$

The null and alternative hypotheses for the unit root test are as follows:

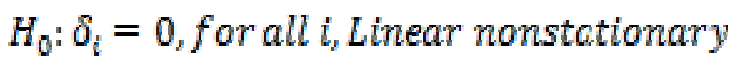

$H_{1}: \delta_{i}<0$, for all $i$, Nonlinear stationary

Uçar and Omay (2009) made calculations based on the standardizing averages of the individual KSS statistics. The test statistics can be shown as follows:

$t_{i, N L L}=\frac{\Delta y_{i}^{\prime} M_{t} y_{i, t-1}^{3}}{\sigma_{i, N L}\left(y_{i, t-1}^{g} M_{i} y_{i, t-1}\right)^{3 / 2}}$

The normalization formulae and table values are presented in the article by Uçar and Omay (2009).

The other test used in the study is the nonlinear panel unit root test developed by Emirmahmutoğlu and Omay (2014). This test is the adapted version of the Sollis (2009) individual unit root for panel data. As it is the case with Uçar and Omay (2009) test, the model that is going to be used to calculate the test statistics by using the Taylor approximation is going to be as follows:

$\Delta y_{i t}=\phi_{1 i} y_{i, t-1}^{3}+\phi_{2 i} y_{i, t-1}^{4}+\varepsilon_{i t}$

The nonstationarity null hypothesis for the Emirmahmutoğlu and Omay (2014) test is $H_{0}: \phi_{1 i}=\phi_{2 i}=0$ for all $z$. The proposed test statistics was computed by taking the average of the individual $F$ statistics.

$\bar{F}_{A E}=N^{-1} \sum_{i=1}^{N} F_{t, A E}$

The panel $\bar{F}_{A E}$ test statistics has a nonstandard distribution and the exact critical values of this test statistics can be computed via stochastic simulation for different values of N and T (Emirmahmutoğlu and Omay (2014). Emirmahmutoğlu and Omay (2014) use the Sieve bootstrap methodology proposed by Chang (2004) to obtain the empirical distributions of $\bar{F}_{A E}$.

Revista Galega de Economia: https:/ / ideas.repec.org/ s/ sdo/ regaec.html 